Man and Nature

L'homme et la nature

\title{
The Camera Obscura or the Optics of Realism
}

Hans-Günther Schwarz

Volume 8, 1989

URI : https://id.erudit.org/iderudit/1012597ar

DOI : https://doi.org/10.7202/1012597ar

Aller au sommaire du numéro

Éditeur(s)

Canadian Society for Eighteenth-Century Studies / Société canadienne d'étude du dix-huitième siècle

ISSN

0824-3298 (imprimé)

1927-8810 (numérique)

Découvrir la revue

Citer cet article

Schwarz, H.-G. (1989). The Camera Obscura or the Optics of Realism. Man and Nature / L'homme et la nature, 8, 63-72. https://doi.org/10.7202/1012597ar

Copyright (C Canadian Society for Eighteenth-Century Studies / Sociéte canadienne d'étude du dix-huitième siècle, 1989
Ce document est protégé par la loi sur le droit d'auteur. L'utilisation des services d’Érudit (y compris la reproduction) est assujettie à sa politique d'utilisation que vous pouvez consulter en ligne.

https://apropos.erudit.org/fr/usagers/politique-dutilisation/ 


\section{The Camera Obscura or the Optics of Realism}

The camera obscura assists the painter, as Delacroix claims, 'in his impetuous desire to render the thing he sees. ${ }^{1}$ It makes possible 'accuracy of the eye' and is, again in Delacroix's words, 'an ancient process, already employed by Leonardo da Vinci, Albrecht Dürer, and others. In it one uses a small panel through which holes are pierced at various levels, the panel is placed at a certain distance from a piece of reducing glass. The artist looks through one of the holes and draws the outlines of the object or of the landscape as they appear when seen through the glass. ${ }^{2}$ The camera obscura as a mechanical instrument for the exact representation of perspective and angles was a constantly used visual aid for the Dutch painters of the 17th century. Vermeer's paintings prove how indispensable the camera obscura had become for realist representation. Dutch painters replaced the mathematical construction of classical Italian painting by observation. In the words of one art critic: 'The Dutch artist adds actual viewing experience to the artificial perspective system of the Italians. ${ }^{3}$ Painting as a visual phenomenon began to replace the textual mode of Italian painting. Italian imagery was legitimized by its relationship to prior and hallowed texts. In its highest form Italian painting was 'istoria' - a pictorialized literary text. Italian painting had as its subject matter significant human actions as they were narrated by the Bible, myth, the historians, and the poets. The emphasis was on the mediation of tradition. The understanding of the mind, not immediacy to the eye, was the aim. The Dutch change in emphasis is made clear by the title of one of the most famous books of the 17th century, Comenius' Orbis Pictus (The Visible World Pictured). With Dutch realism a division arose between narrative and descriptive painting and a conflict between art and nature was perceived. One of the earliest Dutch critics, Abraham Ortelius, refers to paintings by Pieter Breugel as works of Nature and points out their opposition to works of art: 'picturas ego minime artificiosas, at naturales appellare soleam. ${ }^{4}$ Joshua Reynolds, while travelling in the Netherlands, voices the opinion about Dutch paintings that 'their merit often consists in the truth of representation alone. ${ }^{5}$ According to his classicistic expectations, works of art were supposed to be imitations of significant human actions and not just descriptions of the world seen. 
This direct, natural vision of Dutch art is the result of the newlyinvented technology of the lens in which the Dutch excelled. The Dutch astronomer and physicist Huygens binds images to sight and seeing rather than to the mind; Kepler defined the human eye itself as a mechanical maker of pictures and equated 'to see' with 'to picture.' This change from a Renaissance emphasis on reading and interpretation to a 17th century emphasis on seeing and representation has been popularized by Michel Foucault in Les mots et les choses and needs no further comment on our part.

Given this context, it is nevertheless surprising that the first antiAristotelian theory of drama in 18th-century Germany, Die Anmerkungen übers Theater by J. M. R. Lenz, written in 1771 and printed in 1774, should mention the camera obscura. This theory shares with all the important 19th century theories of Realism their anti-idealistic base and has to be seen as their foundation. ${ }^{6}$ Rather than imitating, what he sees as historically irrelevant models like the Greeks, and their successors, the French, Lenz urges German playwrights to mirror nature and to stop their 'hinterherzeichnen und nachkritzeln' ['copying and drawing after works of art from other nations and times']. Like Ortelius, he distinguishes between art and nature; the latter is the only base for artistic expression. What attracts the reader to poetry, Lenz maintains, is ' ... nichts anderes als die Nachahmung der Natur, das heißt aller der Dinge, die wir um uns herum sehen, hören etcetera' ['nothing else; but the imitation of nature, that is of all the things around us which we see, hear, etcetera'] ${ }^{7}$ Lenz, in conscious rivalry with Aristotle, uses the concept of 'Nachahmung' [mimesis, imitatio] as the cornerstone of his modern poetics but gives it a completely new meaning. Compared with Aristotle's precept 'that the poet's function is to describe, not the thing that has happened, but a kind of thing that might happen, and what, according to probability or necessity, is possible, ${ }^{8}$ the Lenzian concept of imitation is limited to a rendition of what can be grasped empirically. The Aristotelian mode of potentiality which transcends the empirically real is excluded. And so are the notions of a pre-established order, unity, necessity or entelechy which the Greek poet strives to imitate.

For Lenz, accidental empirical impressions form the basis of poetry; these are not subjected to notions of harmony and a divine a priori order. Therefore the notions of unity and order which define Aristotelian poetics, and which find their formal expression in the 'unities,' have lost their function. For the empirical observer any sense of a totality or unity is impossible. The accidental and particular replace the whole as the guiding principle: 'Denn die Natur ist in allen ihren Wirkungen mannigfaltig ...' ['Because nature in all its workings is 
varied']. ${ }^{9}$ Instead of an all-encompassing unity, which for the Greeks was held together by mythos and ethos, the 18th-century dramatist sees only 'die unendliche Mannigfaltigkeit der Handlungen und Begebenheiten in der Welt, ['the infinite variety of actions and happenings in the world']. ${ }^{10}$ Variety rather than unity is the characteristic of reality in modern times. The grasping of reality is not, as was the case in antiquity either total or instant, but at best 'sukzessiv': ' - so viel ist gewiß, daß unsere Seele vom ganzen Herzen wünscht, weder sukzessiv zu erkennen, noch zu wollen. Wir möchten mit einem Blick durch die innerste Natur aller Wesen dringen, mit einer Empfindung alle Wonne, die in der Natur ist, aufnehmen und mit uns vereinigen. Fragen Sie sich, m.H., wenn Sie mir nicht glauben wollen. Woher die Unruhe, wenn Sie hie und da eine Seite der Erkenntnis beklapst haben, das zitternde Verlangen, das Ganze mit ihrem Verstande zu umfassen, die lähmende Furcht, wenn Sie zur anderen Seite übergehen, werden Sie die erste wieder aus dem Gedächtnis verlieren' [' - this much is certain that our soul, with all its heart, wishes not to grasp reality successively. We would like to penetrate the innermost nature of all beings with one glance, with one emotion grasp all the joy which is in nature and unite it with ourselves. Ask yourselves, gentlemen, if you don't wish to believe me. Where does that unrest come from, when you have managed to touch one single aspect of truth, that trembling desire to understand the whole, the paralysing fear that you will lose from your memory that first single aspect when you start looking at another one']. ${ }^{11}$

The inability to grasp the totality of life is the core problem of modern art and thought. Lenz prepares the ground for the future discussion of this problem by Schiller and Goethe. Their thought is summed up by Matthew Arnold's dictum on the difference between the Greeks and the moderns: "They regarded the whole; we regard the parts. With them, the action predominated over the expression of it; with us, the expression predominates over the action. ${ }^{12}$ Lenz diagnoses the loss of the 'naive' state of the world, to use Schiller's terminology, and the resulting existential and cognitive problems: 'woher dieser Sturm, das All zu erfassen, der Überdruß, wenn ihrer keichenden Sehnsucht kein neuer Gegenstand übrig zu bleiben scheint - die Welt wird für sie arm und sie schwärmen nach Brücken' ['where does that tempestuous urge come from to grasp the whole, the ennui when no new aim seems to remain for your striving and longing - the world has become impoverished for you and you search desperately for bridges'] ${ }^{13}$

Lenz shows up the dilemma of the modern realist poet. Like the realist painter, he is unable to transcend the object world. Any attempt to reconcile the real and the ideal fails because the ideal is outside the 
object world. The realist poet is no longer able to grasp the whole, to move from the 'parts' to the general. To quote Schiller, the modern poet no longer has any consciousness of a 'harmonizing totality' ['harmonierenden Ganzen']. ${ }^{14}$ The creative possibilities for the modern artist are limited to the representation of his own subjective and visual perspective: 'Den Gegenstand zurückzuspiegeln, das ist der Knoten; die nota diacritica des poetischen Genies ... ' ['To mirror the object, that is the Gordian knot; the nota diacritica of the poetic genius']. ${ }^{15}$ The poet is bound by the finite world; he can only reflect the reality of the world 'as it is' but he cannot go beyond.

It is in this context that Lenz mentions the camera obscura. His comments are illuminating for any study of the realist method. The camera obscura, according to Lenz, is indispensable in representing reality. It makes the object world 'gegenwärtig und anschaulich' ['visually present and real'] ${ }^{16}$ but it does not yet produce art. In contrast to late 19th century naturalistic theory, art for Lenz is ' - nicht Mechanik - nicht Echo - ' ['not a mechanical rendition - not an echo - ']. ${ }^{17}$ Lenz's artist interposes his subjectivity between the world and its artistic representation. While trying to preserve the 'vis ingenii' of the poet, the dependence on the senses poses a problem. Indeed, one cannot rely on the senses to grasp an object: 'Die Sinne, ja die Sinne - es kommt freilich auf die spezifische Schleifung der Gläser und die spezifische Größe der Projektionstafel an, aber mit alledem, wenn die Camera obscura Ritzen hat - ' ['The senses, yes the senses - everything depends on the specific cut of the lenses and the specific size of the projection panel, but given all that, what if the camera obscura has cracks - ']. ${ }^{18}$ Anticipating Kant's scepticism vis-à-vis empirical cognition, Lenz argues that the creation of an artwork demands more than a mere reflection of the empirical grasp of the object world. Having a 'Standpunkt,' a 'point of view,' is a precondition for the poet: 'Der wahre Dichter verbindet nicht in seiner Einbildungskraft, wie es ihm gefällt, was die Herren die schöne Natur zu nennen belieben, was aber mit ihrer Erlaubnis nichts als die verfehlte Natur ist. Er nimmt Standpunkt - und dann muß er so verbinden. Man könnte sein Gemälde mit der Sache verwechseln und der Schöpfer sieht auf ihn hinab wie auf die kleinen Götter, die mit seinem Funken in der Brust auf den Thronen der Erde sitzen und seinem Beispiel gemäß eine kleine Welt erhalten' ['The true poet does not join the parts in his imagination as he likes; this is what the gentlemen like to call 'belle nature,' but with your permission, it is nothing but Nature missed. The poet establishes a view point - and then he cannot join the parts in any other way. One could mistake his painting with the object and the creator looks down on him as on the little gods who sit on the thrones of 
this earth with his spark in their chest and uphold a small world according to his example'. $]^{19}$

The apparent allusions to Shaftesbury's 'second maker' or Leibniz's 'petits Dieux' in this passage have to be seen as quite different from the Renaissance 'alter deus' tradition. Lenz's creator takes a 'Standpunkt' and duplicates reality as it is; in the tradition of Dutch painting, he does not presume to order the world. This ordering of the world was part of the artistic mission until Lessing's time. The Lenzian world finds its meaning in itself and is not part of a larger transcendental and harmonious order, as was 'la belle nature' in its original sense. The implications for painterly or literary composition are clear from Lenz's advocacy of the open form. Open form signifies the replacement of the sequential, harmonizing structure of traditional drama by a simultaneous structure, by a montage of disparate elements. ${ }^{20}$ These disparate elements are a reflection of the increasingly fragmented world view in modern times. We have already referred to the notion of 'Mannigfaltigkeit' [variety of actions and characters]. The only unifying factor is the 'Standpunkt' of the poet - a subjective point of view instead of the traditional all-encompassing totality.

One critic maintains that Lenz's use of the camera obscura corresponds to Leibniz's 'point de vue. ${ }^{21}$ This ignores the fact that the Leibnizian 'point de vue' is still guided by absolute knowledge. The Lenzian 'Standpunkt,' like the camera obscura, can only offer segments or fragments of reality. Working with the camera obscura necessitates a fragmenting approach. Indeed fragments are becoming thematic in Dutch art. Alpers points out Saenredam's additive approach to architectural space which corresponds to Hoogstraaten's additive understanding of perspective. The same attitude is expressed by Saenredam when he praises the beauty of a bit of an apple tree core seen through a crystalline lens. ${ }^{22}$

This fragmenting approach of Dutch art is analogous to Lenz's concept of the open form in which no need is felt to order or assemble individual views into a unified sense of a whole. His concept of dramatic form mirrors the camera obscura technique. In the words of Alpers, "The attitude is conditional on a double fragmentation: first, the viewer's eye is isolated from the rest of his body at the lens; second, what is seen is detached from the rest of the object and from the rest of the world. A contrast can be made between such fragmentary beauty, a function of infinite attentive glances, and a notion of beauty that assumes the just proportion of a whole and thus admits to a prior notion about what makes an entire object beautiful. The prime example for Renaissance picturemakers of beauty so conceived was the justly proportioned human body - constructed or imagined, but never seen. ${ }^{23}$ 
Lenz contrasts the two types of beauty, the proportioned and the natural one, by using an example from landscape gardening. His opposition of the French and English garden corresponds to the two types of drama, the classical or closed one and the modern or open one. The analogy to Italian and Dutch painting is obvious. Lenz strives for 'Wahrheit und Ausdruck' ['truth and expression'] in his writing. His realist aim is accomplished by the following method: 'alles scharf durchdacht, durchforscht, durchschaut - und dann in getreuer Nachahmung zum andernmal wieder hervorgebracht' ['everything deeply thought about, scrutinized, penetrated - and then recreated by an exact imitation']. ${ }^{24}$ Lenz's concept of exact imitation is in clear contrast to the objectivistic views on art held by the Enlightenment. As he states: 'Der schöne Geist kann das Ding ganz erkennen, aber er kann es nicht wieder so getreu von sich geben, alle Striche seines Witzes können's nicht' ['The beautiful mind may know an object completely, but he is not capable of recreating it faithfully, all the strokes of his wit cannot do so']. ${ }^{25}$

The reason for this inability to give a realistic depiction lies in the objective premise of traditional aesthetics. The aim of artistic representation is the expression of the general. All art is orientated towards a general principle as manifested in the divine harmony and order. We can see this in the thinking of Batteux: 'Sur ce principe, il faut conclure que si les Arts sont imitateurs de la Nature, ce doit être une imitation sage et éclairée, qui ne la copie pas servilement, mais qui choisissant les objets et les traits, les présente avec toute la perfection dont ils sont susceptible. En un mot, une imitation où en voye la $\mathrm{Na}$ ture, non telle qu'elle est en elle même, mais telle quelle peut être, et qu'on peut la concevoir par l'Esprit. ${ }^{26}$ There is no visual immediacy; the object world as such is of no concern to the artist. Batteux's thoughts on art resemble Alberti's theories, which shaped Renaissance art and thought. The common ancestor Aristotle is easily recognizable. The world we see in the Albertian sense is the product of the human maker and his ordering mind. The artistic subject defines the object, embellishes it and perfects it in analogy to the divine act of creation. Solger's idealistic 19th-century aesthetic theory continues this view of art: 'Die Kunst schafft aus dem Innersten der menschlichen Natur etwas Objectives, das so, wie sie es geschaffen hat, als bloßer Stoff der Wahrnehmung nicht da ist. Selbst das Dargebotene können wir nur als schön betrachten, wenn wir einen Gedanken darin verwirklicht finden, der sich in der Natur nicht vorfindet' ['Art creates from the innermost part of human nature something objective which, the way art has created it, simply does not exist as a mere matter for perception. We can consider the presentation as beautiful only if we find in it a thought realized which does not exist in nature' $].{ }^{27}$ Aristotelian or idealistic art 
avoids any connection with the human eye or its equivalent, the camera obscura. Anti-aristotelian art, as Lenz formulates it, describes the world as it is seen. The camera obscura becomes its paradigm.

Lenz's mirroring of nature which is firmly rooted in empirical perception has consequences for the depiction of man. He can only be shown in his dependence on nature, as part of the object world and unable to transcend it. Therefore the individual can no longer be used to demonstrate general notions of virtue or vice. Lenz puts his emphasis on the character (the individual and particular) rather than the action (the general). The character's actions are contingent on 'Zufall,' chance, instead of a divine plan.

Whereas Batteux demands the unity of action and character, an expression of the mutual interdependence of the general and the particular, the character becomes the maker of the action in Lenz's programme for a new drama. His concept of the 'handelnden Menschen,' a godlike creature fully responsible for his own fate, remains theory, however. In the practice of his plays he does not see man as free - the individual is seen solely as a plaything of social forces and not able to transcend the world around him; he is observed by the poet in the same detached way as a Dutch painter would observe a domestic interior. Both, Lenz and Dutch realism, produce a 'peinture des détails' which a contemporary of Lenz, Gerstenberg, sees as typical of Shakespeare's work. Lenz sees Shakespeare as the model for modern writers and praises his realism. Lenz's goal in his representation, 'die Natur mutterfadennackt auszuziehen' ['to undress nature until it is completely naked'], does not allow for idealization or harmonization. As a realist, Lenz denies the metaphysical perfection of man and nature; he sees, like Shakespeare, only the 'Mannigfaltigkeit.' This variety interests Lenz because of its characteristic elements. These may be ugly rather than beautiful. The 'Mannigfaltigkeit' is the very opposite of the concept of order which we find in Gottsched's statement: 'Das genaue Verhältnis, die Ordnung und richtige Abmessung aller Teile, daraus ein Ding besteht, ist die Quelle der Schönheit' ['The exact proportion, the order and correct measurement of all the parts of which an object consists, this is the source of beauty']. ${ }^{28}$

Creating an ideal, as the Italian Renaissance painters or the Aristotelian writers did, is no longer a possibility for Lenz. In opposite pairs like idealistic-characteristic and general-particular he expresses the differences between traditional and modern aspirations of artistic creation. For Lenz characteristic representation is the more demanding one: ' - nach meiner Empfindung schätz ich den charakteristischen, selbst den Karikaturmaler zehnmal höher als den idealischen, hyperbolisch gesprochen, denn es gehört zehnmal mehr 
dazu, eine Figur mit eben der Genauigkeit und Wahrheit darzustellen, mit der das Genie sie erkennt, als zehn Jahre an einem Ideal der Schönheit zu zirkeln, das endlich doch nur in dem Hirn des Künstlers, der es hervorgebracht, ein solches ist' [' - in my opinion I esteem the painter of the characteristic, even the painter of caricatures ten times higher than the painter of the ideal, hyperbolically speaking, because it takes ten times as long, to represent a figure with even that exactitude and truthfulness, with which the genius recognizes it, as it does to spend ten years drawing circles to reach an ideal of beauty which exists as such solely in the brain of the artist who produced it'] ${ }^{29}$

The ideal is not verifiable by the senses nor can they create it. The ideal puts the mind over the senses. Realist art is verifiable by a comparison with its model and has an undeniable documentary bent. In the Rezension des Neuen Menoza Lenz comments on his own artistic method: 'Glaubt man etwa, ich habe aus der Luft gegriffen, was bei mir halbe Authentizität eines Geschichtsschreibers ist?' ['Do people perhaps believe that I have invented what in my case is almost the authenticity of a historian?']. ${ }^{30}$ We should remember that Aristotle distinguishes between poet and historian. Only the latter concerns himself with the representation of the world as it is.

The realist poet takes on the function of the historian in the Aristotelian sense. As the examples of Lenz, Büchner and Brecht show, the realist poet defines himself by a rigorous anti-idealism. The human eye, and not the human mind, becomes the sole arbiter of reality. Even if Lenz imposes his 'Standpunkt' on the camera obscura, we must not forget Ann Banfield's observation: 'It may be true that the lens captures in its relation to what it focuses on the stance or point of view of any subject looking through it, but the image on its glass is nevertheless independent of the mind behind, registering this image and representing it to itself. ${ }^{\prime 31}$ This dooms the artist to a dependence on reality. Unwillingness or inability to transcend it are the mark of realist writing as we find it in the 18th and, especially, the 19th century. Both German Classicism and Romanticism took issue with realism and the camera obscura. Goethe demands that art transcend reality: 'denn das wirkliche Sehen ist, sowohl in dem Auge als an den Gegenständen durch unendliche Zufäylligkeiten bedingt' ['because looking at reality is conditioned by infinite accidentals - in the eye as well as the objects regarded']. ${ }^{32}$ For Goethe, as for the Romantics, the human eye without governance from an ordering mind can only reflect the accidental and the chaotic - the very subject matter of realist art and literature. The camera obscura made the human eye the instrument of artistic production. It replaced the ideal by the real. In that it followed the scientific orientation of the modern age. The camera obscura-approach be- 
came the writer's method of documenting the world as it is. Art and life became one - until they were separated again by Symbolism and other anti-empirical movements. Picasso's 'I paint what I think' proves his dissociation from the eye as a foundation of contemporary artistic method.

\section{HANS-GÜNTHER SCHWARZ}

Dalhousie University

\section{Notes}

1 Eugene Delacroix, The Journal, ed. Walter Pach (New York: Covici, Friede, 1937), p. 713.

2 Delacroix, p. 713.

3 Svetlana Alpers, The Art of Describing. Dutch Art in the Seventeenth Century (Chicago: The University of Chicago Press, 1983), p. 27.

4 Wolfgang Stechow, ed., Northern Renaissance Art 1400-1600 (Englewood Cliffs, N. J.: Prentice Hall, 1966), p. 37.

5 Alpers, p. xviii.

6 Cf. Hans-Günther Schwarz, Dasein und Realität (Bonn: Bouvier, 1985), p. $11 \mathrm{ff}$.

7 J. M. R. Lenz, Werke und Schriften I, ed. Britta Titel und Hellmut Haug (Stuttgart: Goverts, 1966), p. 333.

8 Aristotle, On the Art of Poetry, ed. Ingram Bywater (Oxford: Clarendon Press, 1909), 1451a,9.

9 Lenz, p. 350.

10 Lenz, p. 351.

11 Lenz, pp. 334-35.

12 Matthew Arnold, Poetical Works (Oxford: University Press, 1966), p. xxi.

13 Lenz, p. 335.

14 Friedrich Schiller, Werke, ed. Herbert G. Göpfert (München: Hanser, 1966), p. 557.

15 Lenz, p. 336.

16 Lenz, p. 336.

17 Lenz, p. 336.

18 Lenz, pp. 335-36.

19 Lenz, pp. 336-37. 
20 Cf. Hans-Günther Schwarz, 'Shakespeare and Eighteenth-Century German Poetics,' in Man and Nature, vol. IV, ed. David Jory and Charles Stewart Robertson (Edmonton, 1985), 179.

21 Titel, Werke I, pp. 653ff. The reference is to Leibniz's monad (Monadologie 157; Principes \3).

22 Cf. Alpers, p. 85.

23 Alpers, p. 85.

24 Lenz, pp. 338-38.

25 Lenz, p. 338.

26 Charles Batteux, Les Beaux Arts réduits à un même Principe (Geneva: Slatkin, 1969), p. 33.

27 K. W. F. Solger, Vorlesungen über Ästhetik, ed. Karl Wilhelm Heyse (Darmstadt: Wissenschaftliche Buchgesellschaft, 1969), p. 3.

28 Christoph Johann Gottsched, Ausgewählte Werke VI,I, ed. Joachim Birke and Brigitte Birke (Berlin, New York: de Gruyter, 1973), p. 189.

29 Lenz, p. 342.

30 Lenz, p. 416.

31 Ann Banfield, Unspeakable Sentences (Boston: Routledge \& Kegan, 1982), pp. 273-74.

32 Wolfgang Goethe, Werke, Bd. XII (Hamburg: Wegener, 1963), Heidelberg, p. 158. 